\title{
Implementation of Prosocial Education Through Experiential Learning in the Subject of Kemuhammadiyahan
}

Received:28-12-2020; Revised:09-06-2021; Accepted:12-06-2021

\section{Ilham Mundzir}

Universitas Muhammadiyah Prof. Dr. Hamka

Jakarta, Indonesia

E-mail: ilhammundzir@uhamka.ac.id

\begin{abstract}
Prosocial education is an educational program to increase motivation and skills of the student to help, care for others in need. This article is aimed at analyzing the implementation of prosocial education in the Kemuhammadiyahan subject. Using experiential learning method, students not only learn about Muhammadiyah from an organizational, historical and ideological perspective, but also experience and practice al-Ma'un theology in carrying out da'wah empowerment of the duafa family. This research design was a descriptive qualitative. The data were collected by making observations during the activity, interview, and documentary studies. Using content analysis, this study found that this da'wah for empowerment of the duafa family was in line with the objectives of prosocial education, namely increasing empathy and concern for the mustad'afin group
\end{abstract}

\begin{abstract}
Abstrak: Pendidikan prososial merupakan konsep pendidikan yang didesain agar peserta didik memiliki motivasi dan keterampilan untuk membantu, peduli terhadap orang lain yang membutuhkan. Artikel ini ditujukan untuk menganalisis praktik pendidikan prososial yang dilakukan dalam mata kuliah Kemuhammadiyahan. Dengan menggunakan experiental learning, mahasiswa tidak hanya belajar tentang Muhammadiyah dari sisi organisatoris, historis dan ideologisnya an sich, melainkan mengalami dan mengamalkan teologi al-Ma'un melaksanakan dakwah pemberdayaan keluarga duafa. Desain penelitian ini adalah deskriptif kualitatif. Data dikumpulkan dengan melakukan observasi selama kegiatan berlangsung, wawancara, dan menganilisis laporan dakwah pemberdayaan keluarga duafa setiap kelompok. Menggunakan analisis isi sebagai metode analisis datanya, penelitian ini menemukan bahwa dakwah pemberdayaan keluarga duafa ini sejalan dengan tujuan pendidikan prososial, yakni meningkatkan empati dan kepedulian terhadap kelompok mustad'afin.
\end{abstract}

Keywords: Prosocial Education, Kemuhammadiyahan, Experiential learning, Poverty Alleviation 


\section{INTRODUCTION}

$\mathrm{T}$ The world today is experiencing extreme poverty. A report states that two-thirds of the world's population is in acute poverty, and lives on less than one US dollar a day. Not much different, the poverty rate in Indonesia reached 24.79 million in September 2019 (www.bps.go.id). This poverty rate can certainly increase, along with the Covid-19 pandemic at the beginning of 2020. In the midst of the poverty phenomenon, in the context of education, there is a phenomenon where educated people are far from society.

A study reported that in Europe, antisocial phenomena emerged among students who had enjoyed a good education. With good educational facilities that have been received from the government, it does not guarantee to produce good citizens who have concerns toward their surroundings. Rather, they increasingly becoming highly individualized in membership in the society, so that the concept of citizenship (citizenship) loses its relevance and meaning, and has a broad impact on the loss of responsibilities as citizens. They lose the ethos of solidarity, togetherness, and social sensitivity to the surrounding environment. Using the perspective of Hannah Arendt, the phenomenon where educational institutions fail to educate their students to become citizens of high social responsibility, then in fact education can be said to be in a very dangerous crisis state (Welply, 2019).

These various phenomena seem to strengthen the idea that the challenges of the times are not enough to be solved by relying on education that only focuses on increasing the intelligence or cognitive aspects of students. In fact, in a world that is rapidly changing due to globalization and technological developments, there are still problems of very high socio-economic inequality and injustice between community groups that require change agents with high social sensitivity. The changing landscape in this global society raises questions about what skills students must possess when studying at educational institutions in order to have the responsibility to carry out social transformation for the good of the community in their environment.

Unfortunately, in many practices, education is still a mere transfer of knowledge. In fact, the concept of education which is only intended to transfer knowledge, improve cognitive skills to achieve high grades through a series of certain tests from lecturers or teachers to students or students have long received a series of criticisms. Education experts are starting to realize that the essence of education goes beyond the mere transfer of knowledge but is prioritized to increase the virtues and morals of students, to grow the character of participants who can later support success in social life such as responsibility, caring, cooperation, and so on. (Baehr, 2017). In addition, in the context of higher education, education is also aimed at shaping students to become good citizens who are able to live co-existence with other citizens regardless of their social, cultural, and religious background.

Therefore, simply equipping students with only academic abilities is clearly not sufficient to help them succeed in real life and help the progress of society. Students sit passively in class to memorize knowledges, information does not help much progress in society. Universities are required to start thinking about ways to equip their students with personal and social competencies that make them ready to integrate with society and real life. Religious education in higher education requires another approach model that can bring students into citizens who have high social awareness.

The Kemuhammadiyahan course is one of the compulsory subjects and is included in the Islamic religion (education) class at the Muhammadiyah Higher Education. Generally, this course is delivered using a historical approach, an ideological approach and an introduction to the Muhammadiyah organization to students (Pasha and Darban, 2009). This approach prioritizes the 
cognitive aspect where students understand and understand Muhammadiyah including the background of its establishment, the purpose of its establishment, its ideology or religious understanding, and its organizational activities.

\section{METHOD}

The design of this research was a descriptive qualitative, namely explaining and understanding how prosocial education is implemented based on religion, in this case, al-Ma'un's theology as the basis. Data were collected by observing during the da'wah activity for empowering the poor family, starting from the stage of searching for the poor family, collecting donations, and distributing aid. After the process was completed, interviews and documentation studies were carried out by collecting reports on empowerment da'wah activities carried out by the team. The data that has been collected is then analyzed using content analysis techniques or content analysis. The respondents of this study were students who had completed the da'wah for empowering disadvantaged families in the Kemuhammadiyahan course for the 2019/2020 school year.

The operational definition of content analysis used here generally refers to the description given by Haggarty, who says that content analysis is a technique of drawing conclusions systematically and objectively on the information submitted by students, both data submitted verbally and written documents in report. These conclusions are then classified based on certain themes and then discussed with relevant theories (Haggarty, 1996). Both data submitted verbally and written documents in the report. These conclusions are then classified based on certain themes and then discussed with relevant theories (Haggarty, 1996) both data submitted verbally and written documents in the report. These conclusions are then classified based on certain themes and then discussed with relevant theories (Haggarty, 1996)

\section{RESULTS AND DISCUSSION \\ Prosocial Education Ideas}

With the the argument that education should be able to teach students to have a social concern for the unequal reality in their environment, the experts then offered the concept of prosocial education. Unfortunately, in Indonesia the concept and the idea of prosocial education is not yet popular enough compared to a number of contemporary educational discourses such as multicultural education, gender equity education, and human rights education-to name a few. Apparently, prosocial education has not become a priority concern. In fact, prosocial education is one of the keys that can encourage, integrate students into real life in society, teach the importance of responsibility in a shared life.

The concept of prosocial has long been known in the field of psychology. Prosocial behavior generally refers to the meaning as a voluntary action to benefit others in various ways such as helping, cooperating, donating, and sharing (Spinrad and Gal, 2017). It includes altruism whose goal is to improve the welfare of others. Therefore, if it turns into prosocial education, it generally includes all planned efforts made by an educational institution aimed at fostering prosocial behavior among its students (Spinrad and Gal, 2017).

With the implementation of this prosocial education, it is hoped that students will experience changes in the aspects of the head (cognitive), heart (affective or motivational), and hand (behavior) in relation to the community. Learners have a strong sensitivity, awareness, and motivation to care, be productive and help the surrounding environment, especially for people in need. D' Alessandro, 2012). Prosocial behavior, including volunteerism, is one of the important things to promote the spirit of society. So, students are not alienated, isolated but integrated and ready to plunge into their social environment.

In order to improve culture and prosocial values for adolescents, it is very important to 
provide opportunities and opportunities for them to be able to struggle with the pulse and daily activities of people's lives through various activities. It is also important in order to erode the anti-social tendencies of adolescents (Cheung, 2006). Various activities that directly interact with the community, especially those in need, can encourage the importance of helping others, having a strong will to help others, and enjoying these activities.

Prosocial activities or behaviors are not only beneficial for society, but also bring benefits for themselves such as enjoying friendships, helping to position themselves and their role in society. A study in Hong Kong proved that with students doing lecture assignments that have a dimension of direct contact with the community, it is able to encourage voluntarism and prosocial behavior among adolescents (Cheung, 2006).

Prosocial education is a very broad concept. The implementations vary. There is no standard form. Several important components in prosocial education are: First,

prosocial education involves elements of academic, emotional, and social development. Second, students learn to identify social problems, provide solutions or solutions, and initiate appropriate forms of empowerment programs for the problems of poor families they face. Third, providing opportunities for students to carry out social service projects to others. Fourth, in its implementation, students work together,

collaborate with the wider community or other parties such as companies, nongovernmental organizations. Fifth, students can get values and learn from social activities that have been carried out (D'Alessandro, 2012).

\section{Muhammadiyah and the Spirit of Prosocial Behavior}

Before explaining the practice and implementation of prosocial education in this Muhammadiyah course, I will first explain Muhammadiyah itself. Muhammadiyah is the largest modern Islamic organization in
Indonesia. As an Islamic movement, Muhammadiyah is also known as a social movement with a trident; feeding, schooling and healing through a number of charities in the field of education and hospitals. Now Persyarikatan is developing a new trident concept, namely MDMC (Muhammadiyah Management Disaster Center), Community Empowerment Council (MPM), and LazisMu. Thus, there are six (6) areas that are the focus of the Muhammadiyah movement.

As explained above, the education field is one of the six tridents that are the concern of Muhammadiyah. In the field of education, the organization founded by Kiai Haji Ahmad Dahlan has advanced the Indonesian people with its services ranging from the Bustanul Athfal (Kindergarten) level to the higher education level. Historically, before establishing Muhammadiyah, Kiai Ahmad Dahlan had made education his priority by transforming his house the forerunner of a school for poor children in the surrounding environment.

The basic ethos of Muhammadiyah education cannot be separated from the goal of Muhammadiyah itself, namely education as a means of preaching enlightenment (tanwir) in order to free society from backwardness and ignorance while educating and advancing the people. Education that not only educates the mind but also revives the heart so that it can grow awareness of divinity and devotion to Allah SWT. With such an educational basis, it is hoped that a generation of Muslims who have good morals are capable, have self-confidence, and most importantly are useful for society (Baidhawy and Khoirudin, 2017).

As part of such Muhammadiyah educational principles, the concept of Muhammadiyah education also provides a pressure point so that students can transform into individuals who are beneficial to others, have a compassionate nature (compassion), and fostering the spirit of helping students themselves. This approach is clearly different from the goal of education with the 
paradigm of liberalism and capitalism which is oriented to the side of economic achievement alone.

In the context of liberalism and capitalism, for example, education is no more than to achieve material prosperity. In such a perspective, higher education was created to meet the need for a professional labor market, with qualified soft and hard skills, and to fill the employment with higher positions so that have an impact on higher incomes. Therefore, it is not surprising that for many parents and students, the purpose of attending higher education is so that their children will get a better income and welfare in the future. The higher the level of education, the better of winning the competition for job struggle. Therefore, many from the lower class of society even send their children to higher education no matter what the cost. Thus, higher education is a way to carry out social mobility (Bathmaker et. all, 2016)

However, this is not the case with Muhammadiyah's educational vision. The nature of compassion, social care is an important vision of Muhammadiyah education. Zamahsari, in the introduction to the book Kemuhammadiyahan emphasized that this Kemuhammadiyahan course uses a new approach. Students are not introduced to Muhammadiyah using the concept of learning by listening as it is common in content-based learning, but using a learning by doing approach which was introduced in the experiential learning method (Zamahsari, 2018). This theory was originally developed by David A. Kolb in the 1970s which is generally intended as a process in which knowledge is acquired by understanding information and then transforming it through direct experience. Pedagogically, the process is formed by creating programs or activities that allow students to be involved in activities and processes of knowledge discovery and gain learning experiences; including understanding what skills, both soft skills and hard skills are needed, which are required to be able to achieve that understanding and knowledge (Lai \& Hui, 2020).

The idea of "learning by doing" from this experiential learning theory was inspired by a number of pedagogical figures such as John Dewey and Jean Piaget. Kolb's experiential learning theory (ELT) offers experience as a very important concept in the learning process. This theory is different from the cognitive theory approach which emphasizes the mastery of abstract concepts and symbols as well as behavioral learning theory which often ignores awareness and subjective experience in the learning process. However, experiential learning theory is not intended to negate the two theories, but rather to complement and integrate, so that the learning process needs to combine experience, perception, cognitive, and behaviorism dimensions (Kolb, 2015).

Kolb (2015). defines experiential learning as a process of discovery, the creation of knowledge through the transformation of an experience. So, knowledge is obtained through a combination of processes of obtaining information from experiences and then interpreting the various information that has been obtained. The concrete experiences gained are observed and reflected, conceptualized in an abstract way, and then transformed into ideas or actions. Thus, learning in the view of experiential learning theory includes four (4) activities as follows: experiencing, reflecting, thinking, and acting (Kolb, 2015, 51).

By applying experiential learning, students benefit from getting the final results of learning more deeply and broadly (Coker, Heiser, Taylor, 2017). For this reason, experiential learning is considered increasingly relevant to the context of changes and developments in the modern era, as a substitute for the model of knowledge transfer from teachers or lecturers to students or students. Although it is not a characteristic and monopoly of experiential learning methods, several activities can be categorized as part of the implementation of experiential learning such as role-play, 
simulations, structured activities, inquirybased activities, and individual reflection (Tomkins and Ulus, 2015).

\section{Kemuhammadiyan and Implementation of Prosocial Education}

As explained above, the Kemuhammadiyahan course at Uhamka has opened new avenues for prosocial education, namely through the empowerment program for poor families. Students who take this Kemuhammadiyahan course are taught at the first stage about the theology of al-Ma'un that the practice of worship is meaningless and useless if the performer is ignorant of the condition of the weak. In fact, the person is said to be a religious liar (AIKA Lecturer Team, 2018).

By emphasizing the teaching of al-Ma'un theology at the beginning of this course, it is hoped that students will have the awareness to carry out religious teachings seriously and be enthusiastic to free mustadh'afin (the oppressed) from oppression (AIKA Lecturer Team, 2018). After getting an explanation about al-Ma'un's theology, which is one of the important values that underlie the establishment of Muhammadiyah, then students are directed to empower poor families.

Students are divided into groups of three students. Each group was given the task of finding nine (9) needy families, and one of the poorest families was selected from the nine families. After determining the most eligible family, students make an empowerment proposal.

Next, students do fundraising both online and offline to the wider community, corporate social funds, and nongovernmental organizations. Students may not ask their parents for money for the purpose of implementing this program. After the funds are collected according to the required target, students carry out an empowerment program. Then, students were asked to make presentations and write reflective articles that described the journey of implementing the program from beginning to end, with an emphasis on prosocial values that were obtained and benefited themselves and the wider social transformation.

From the empowerment activities for disadvantaged families, students have carried out prosocial education which refers to various forms of activities within the scope of educational institutions, both co-curricular and extra-curricular with the aim of promoting students' prosocial values, attitudes and practices (Mundzir and Zamahsari, 2021), which will be described as follows:

\section{Analysing the Various Foces of Poverty}

One of the important elements of prosocial education is that students encounter the phenomenon of poverty in the community. This will be an experience in itself because students see the state of society with their own eyes. The condition of poor families found by a number of groups shows the various conditions of poverty in Indonesia. Axel and Hilmi groups, found that poverty is very complex. Mr. Herry (77 years old), lives in Kebonpala, East Jakarta. He lives in a rented apartment which is far from simple. For his daily needs, he relies on his eldest child, working as a credit counter guard near his house with an income of Rp. 800 thousand/month. The money is only enough to pay for rent, electricity, and rent for a shop. For daily food needs, the family opened a small shop, which was looked after by their second child who had a minor stroke, earning Rp. 300,000 - 400,000/ 2-3 weeks. On the other hand, their third child is still in high school, which costs a lot of money. After fundraising, this group managed to collect data of Rp. 3,165,500, which is used to increase the stall's business capital.

Another group, with the Ayu, Desi, and Ika teams, helped the needy families in the Lebak area, Banten. Ibu Pipit, a widow with 3 small children. The first child is still in elementary school, the second child is not yet in school, and the third is still a toddler. Because her children are still small and 
cannot be left behind, she cannot work. For daily living, Mrs. Pipit was given by her parents Rp. 20,000. Sometimes, the neighbors give food or money. The empowerment program for the underprivileged family is made by building a basic food stall and selling fried foods. The funds collected are Rp. 3,220,000.

Another story discovered by Nurul, Raihanah, and Putri. It is Mrs. Jubaedah who lives in Cikarang. Lives with 4 children, with her husband working odd jobs as well as her husband's younger brother who is unemployed. Her first child has graduated and is looking for a job, the second is still in junior high school, the third is still in elementary school and the last is still a baby. Ibu Jubaedah used to work as a housemaid, but is now abandoned because she has to take care of her baby. Even her husband's income is not enough to meet his needs. The total collected fund was Rp. 3,500,000, which is used to build a stall.

Dewi, Nadya, and Oktavia's group met Ibu Jasiyah, a widow and head of the household who does not work for her two children. The first child works as a construction worker with an uncertain income. Meanwhile, her second child is unemployed due to low graduates, making it difficult to find work in the capital. It's live in a small, untiled rented house in the South Jakarta area, costing Rp. 500,000/month.

Mrs. Jasiyah has expertise in making tempe chips and has the desire to open a business. So, after the fundraising activities managed to collect Rp. 3,780,000, was used to buy equipment and materials for making tempeh chips such as frying pans, filters, tempeh cutting tools, and plastic as well as raw materials such as sago, oil, soybeans, garlic, and white pepper.

The group consisting of Arny, Haninah, and Rizki chose the family of Babeh Ahmad, an elderly person with calcification who makes ends meet by trading rujak and sweets by traveling around. $\mathrm{He}$ lives in a small rented house with his wife and child who do not have regular jobs. The implementation of this duafa empowerment is carried out by helping with selling needs and primary needs, namely by donating selling needs to mattresses and folding walkers with the collected donation funds amounting to $\mathrm{Rp}$. 3,500,000.

Furthermore, Deafitri, Sekar, and Qonita's group helped the family of Minah (43 years old), a widow with 4 children. To support her children by selling hodgepodge and ice. His house does not have its own electricity connection but gets electricity from its neighbor. Minah's dreams of opening a small restaurant. From the fundraising activities carried out, Rp. 3,015,000 which was spent to build a small restaurant.

Nia, Abdul, and Ferly helped Tonya (70 years old) live in Tangerang. In his daily life, he only eats white rice, with only chili and salt. Tempe is an additional side dish that is already classified as special for this family. His income is IDR 350,000/month as a result of wages for peeling onions in the Meruya market. She is the only backbone of his children and grandchildren. Fundraising activities to collect Rp. 3,051,500, which was used to open a shop.

Meanwhile, Dinda, Ellyra, and Haifa helped Mrs. Marhani (64 years old), a widow. At an old ages, he is still working hard to support her self and her fifth child, who works as a clothes maker with uncertain income, and a grandson in the 4th grade of elementary school. In her daily life, Mrs. Marhani works cleaning the house by sweeping and mopping with an income of Rp. 300,000/month starting from 08.00 WIB to 13.00 WIB. Thus, several forms and variants of poverty that exist in society have been found and recorded by students.

\section{Fundraising Experience}

An integral part of the empowerment program for poor families in the Kemuhammadiyahan course related to the practice of prosocial education is the fundraising stage. Students who have discovered the phenomenon of poverty, make proposals for empowerment and 
calculate their funding needs. Students do fundraising both online and offline.

Fundraising activities are one of the most difficult stages in the implementation of the empowerment program for disadvantaged families, but also become one of the factors that facilitate the emergence of empathy and prosocial behavior for the perpetrators. In the context of prosocial behavior, there is a theory called the martyrdom effect. The harder the effort and struggle that is deployed in prosocial activities, the higher the prosocial effect (Olivola and Shafir, 2011).

The findings in this paper are Olovola and Shafir's thesis. With this fundraising activity, students do not only feel difficult it to earn money but also make student involvement in this empowerment program closer and emotional. The closeness of students with needy families is also getting higher. For example, experienced by a group consisting of Aida, Itsnaini, and Marwah. This group, for example, has a program to help Ibu Amih's family in the East Jakarta area. In their fundraising activities, they use a media campaign (social network/internet site) with the aim of getting donors from the widest possible community. The advantage of using social media for fundraising is that it makes it easy for the wider community to make donations anytime and anywhere. Link campaigns were not only created through online platforms but through all social media such as WhatsApp and Instagram. In addition, this group also made posters that were distributed on social media statuses containing complete descriptions of programs and activity plans, the poverty condition of Ibu Amih.

Apart from using social media, this group also uses the direct method by visiting potential donors by bringing a program design that is arranged in a proposal. Each group member is tasked with visiting relatives, friends, and walking around the shophouses or shops in the market located in their respective home areas. Another way is to raise funds by means of business funds or selling, namely selling drinks and food in the environment around the campus. From their fundraising activities, they collected $\mathrm{Rp}$. 3,300,000.

Another story was told by the group of Annisa, Delima, and Rifda who helped Ibu Sri's family in South Jakarta. Sri's mother is a widow with one child. Every day she works as a laundry worker. His income ranges from IDR 50,000 - IDR 100,000/day. He must try to work to support himself and the needs of his son who is in junior high school (SMP). To realize the program, this group conducts fundraising by distributing flyers and proposals online or door-to-door to neighbors. They admit that fundraising does not necessarily go straight. The many obstacles faced starting from the weather factor that often experiences continuous changes sometimes very hot and sometimes heavy rains which have an impact on delaying the time to sell food and soft drinks around Gelora Bung Karno, Car Free Day Jakarta, and around the Monas area on every weekend. In addition, this group is also looking for other alternatives to raise funds, namely through the distribution of proposals to friends, closest relatives, and relatives so that in the end the funds collected amounting to Rp. 3.125.963

Group Fajrina, Fitri, and Jannah made a proposal to help Ibu Sri who lives in the district Tangerang. This family consists of 2 adults and 2 children. Ibu Sri is the backbone of the family, without a permanent job, and only doing washing clothes, scrubbing clothes, helping to be shop keeper, or take care of the neighbors' children. Even this work is carried out if there is a call. If there is no means there is no income for that day. From this work, Mrs. Sri earned Rp. 25,000 to Rp. 50,000/day which is used to meet daily needs for herself and her two children who are still in school; the first child in 4th grade and the second in 1st grade

She actually had a husband, but never gave her a living. Her husband's job as a farmer is not only not enough but also makes him homeless and more often in a hut near 
his rice field. Sri's mother repeatedly asked for a divorce, but her requests were always rejected. Ibu Sri's children can go to school because of the help from the government.

Fundraising method that this group uses various methods. The first is by creating a campaign on an online platform. The second is to circulate the proposal to the family. The responses this group got from family and relatives received different responses, some responded immediately, some criticized, and refused because they didn't have money. The third is asking for help from friends and the community. The responses from each of our friends varied, some immediately sent donations, some had to be in the lobby before donating until some asked to explain in detail the purpose of our goal but in the end did not necessarily donate the money. When asking for help from their community friends, this group admitted that they were a little embarrassed because they had to hurt people. In the end, the collected funds amounted to Rp. 3,025,000.

Another experience was expressed by the Axel and Fadhlan groups carried out various forms of fundraising activities, starting from creating a donation account on an online platform, asking for donations from closest relatives and friends, door to door, to making stickers and then selling them in the campus area. Through the methods mentioned above, we received a fund of Rp. 3,166,000 which was used to buy all the needs of Mr. Yono's stall.

In fact, raising funds through online platforms will not be immediately seen by many people, but must be disseminated. So this group disseminates, namely by posting statuses on all social media they have such as Instagram, Whatsapp, Facebook, Twitter, even include in the Youtube comments column famous influencers. Despite the various obstacles, almost $70 \%$ of the funds that were collected came from the online platform.

In addition, this group is also trying to contact one by one friend or friends who are near or far by sending the link and offering them to donate some of their property. Axel, for example, whenever he visits relatives or relatives, always submits a proposal by first explaining the purpose and objectives of the program. This method is very generally getting a very good response

Based on the experience of this group, the most difficult method is to spread the proposal door to door to the community. Not only have to think about where the area will be if many people donate but also fight the shame in yourself. In addition, convincing the public that this activity is not a fraud is difficult. There are always people who look at them with indifference and seem condescending. But there are also people who are happy to make donations. The attitude of acceptance and trust from these people really helps suppress shame and brings satisfaction because they can invite others to help others.

\section{Self-Development Values}

Experience in direct contact with poverty, and being involved in activities fundraising brings a number of advantages to students in the form of experiences and values, which are stated as follows:

1. The growth of the agency

One of the benefits that students get in experiential learning in this Kemuhammadiyahan course is the emergence of a will, a desire in them to help others. Axel, one of the students, admitted that this empowerment propaganda activity for the underprivileged families has fostered a strong desire to care for others.

"This empowerment da'wah honed my empathy and care for others. The next day, if I am given the opportunity and can generate my own sustenance, I will do this empowerment again. I want to make myself a generation of Al-Maun, help those who are in need, set aside some of my sustenance so that they are happy. I also learned to 
care for others to bring happiness to me. Helpful and happy, makes me happy too,"(Axel).

"Our awareness to share with each other is not only a noble attitude taught by religion. More than that, human thoughts and instincts as social beings always require us to be concerned about all the suffering, shortcomings, and limitations that are felt by others. There is another side of our mind that also suffers or feels guilty when we feel the ease of life with its many facilities, while at the same time we know there are around us that even just meeting the basic needs of life is difficult, "(Nia, Abdul, and Ferly).

"My desire is getting bigger and bigger to help the people around me who need help in terms of food, clothing, and shelter. My sense of gratitude for the blessings that God has given me is also getting bigger because there are many people whose lives are more worrying than I am who are well-off. The existence of the Kemuhammadiyahan course made me open in sympathy and empathy for people in need, and the lessons I learned from helping the needy were very much the most important thing is to be grateful for what I currently have,"(Lia).

From the data above, it appears that Muhammadiyah learning by using an experiential learning approach has succeeded in raising agency awareness in students to behave prosocial to other people or society. This learning has given rise to the principle of student agency. That is, after attending the Kemuhammadiyahan course which is taught using this experiential learning method, students are able to reflect on their interactions with the families and poor communities they are helping and then the desire, determination (will) arises to project it in the future.

\section{Gratitude}

A number of studies show that gratitude mediates prosocial behavior (Yonker, Pendery, Klein, Witte, 2019). It is understood that being grateful for all the blessings from Allah will encourage someone to share. Moreover, religious orders also encourage adherents not only to build good relations with God but also to build good relationships with fellow human beings. However, this research actually proves another finding that helping others actually creates feelings of gratitude. This is understandable because helping others in need allows the person to know the difficulties of others, raises awareness that his condition is much better so that in reflection he appreciates all his conditions.

"From this da'wah activity to empower poor families, we have learned to be grateful for whatever we have because there are still many people who are not as lucky as us. Sometimes you have to look down so you can be grateful and feel enough with what you have. If we always look up, we will continue to be dissatisfied and want more than we have today. To the family of Mrs. Sri, we thank you for receiving us in a kind, friendly, and family-friendly manner. We can also practice empathy to care for the people around us. This Kemuhammadiyahan course has provided important lessons about interpreting the meaning of Surat al-Maun which hopefully will continue to be a provision for us", (Annisa, Pomegranate, Rifda). 
"From the whole process of searching for needy families, preparing proposals, raising funds to implement the program, we can take many values as valuable life lessons. The great value we get is the need to be grateful for what we have. Sometimes we as human beings keep wanting more, bigger things and never reach satisfaction. After seeing Ms. Minah's family, we realized that there are still many other people whose lives are deprived, all mediocre but still willing to try. Sometimes we are still lazy and often complain because of assignments, even though there are many other children who want to go to college but can't afford it. With this activity, we learned that no matter how small we get in life, we should be grateful because it could be the little things that bring goodness and benefit to our lives. From this activity, we also learn to be patient. Be patient when tired or patient when there is a test that Allah gives us. Seeing Minah's mother who was abandoned by her husband and bearing 4 children must have been very hard and difficult, but she was able to endure it patiently. So when we are faced with difficulty or displeasure, we must be sincere and patient through it because Allah will not give difficulty to his servant if he cannot get through it. (Deafitri, Sekar, and Qonita) Be patient when tired or patient when there is a test that Allah gives us. Seeing Minah's mother who was abandoned by her husband and bearing 4 children must have been very hard and difficult, but she was able to endure it patiently. So when we are faced with difficulty or displeasure, we must be sincere and patient through it because Allah will not give difficulty to his servant if he cannot get through it. (Deafitri, Sekar, and Qonita) Be patient when tired or patient when there is a test that Allah gives us. Seeing Minah's mother who was abandoned by her husband and bearing 4 children must have been very hard and difficult, but she was able to endure it patiently. So when we are faced with difficulty or displeasure, we must be sincere and patient through it because Allah will not give difficulty to his servant if he cannot get through it. (Deafitri, Sekar, and Qonita) we must be sincere and patient to live it because Allah will not give difficulty to his servant if he cannot get through it. (Deafitri, Sekar, and Qonita) we must be sincere and patient to live it because Allah will not give difficulty to his servant if he cannot get through it" (Deafitri, Sekar, and Qonita).

"I am so grateful for this program because I can learn that making money is not easy and requires hard work, always be grateful in any circumstances. From this program, I had the opportunity to see down that there are still many of them who are underprivileged, they need help from us who live properly. During this time I always feel lacking because I only look up to, who are more capable than me, there is always something less or not ideal in my life. I spend so much time thinking about what I'm missing, that I no 
longer have time to be grateful

for what I have so far,"(Miftahul).

"Through this empowerment program for poor families, I have learned many life lessons that I can implement. I learned that there are still many people who are not as lucky as me. They work hard to support the necessities of life even though they may not be young anymore. I also learned that gratitude is very important, those who live in poverty are able to be grateful and continue to face life. Honestly, I am ashamed of myself, I am still financed by my parents, living well, food is available every day, but always complaining and demanding something that could actually be postponed,"(Rani).

"The value I get is gratitude. Why? Because they are still given enough extraordinary things in everyday life. When trying to fundraising in this activity is a difficult thing because it does not have any experience and is still learning to be better. With this course, I personally feel very grateful to Allah, that Allah has provided for my parents' sustenance so that I can still experience His blessings without difficulty. There is also a growing sense of caring for others and love. I also believe sharing is beautiful,"(Ellyra).

\section{Cultivating Empathy}

Empathy is generally understood as an affective response that arises when a person understands well the conditions and emotions of others, to the stage of approaching feeling what other people feel or what others expect (Spinrad and Gal, 2018). Empathy has been widely recognized as a factor that facilitates prosocial behavior (Telle \& Psifter, 2015). Fernanda, in his reflection, wrote that the experience of empowering disadvantaged families is not only knowing His commands to help the poor but also being able to carry out God's commands directly. After going through this series of programs, Fernanda admitted that there was a desire to continue to be able to share again with the empowerment of the underprivileged. Another benefit obtained is to increase empathy higher. By providing assistance to people in need, with this activity, besides helping, can also increase the integrity and depth of the relationship between himself and other people and the community. Fernanda felt that previously he was a selfish person because he didn't really care about other people's circumstances, but only thought about himself and his future. But with this activity, his heart was moved to help ease the suffering of others with various forms of assistance that I could provide.

"This activity also made me be grateful for what God has given me. This empowerment program for the underprivileged is momentum for gratitude. In addition, I can feel pain, understand other people's circumstances. I realized that many had a harder life than mine, I stopped to complain about my current situation because it was nothing compared to their suffering, the hardships of their life. This activity also made me more enthusiastic to study and achieve my goals. I don't want my family to live in misery, deprivation. I want to be successful and make my family happy. I want to be a useful person for myself and others. When successful I want to share 
with people in need. This Kemuhammadiyahan course also made me stay motivated to learn, not to be lazy, and to pursue my dreams,"(Fernanda).

"Through this empowerment program for poor families, we get values from empathy in the form of caring attitudes towards the poor, orphans, and people in need. As well as developing social behavior that can become social worship as religion teaches every human being must help each other in goodness which can also be a form of gratitude," (Aida, Itsnaini, and Marwah).

"The meaning of this empowerment program is to train my empathy to be more sensitive to others, to create a sense of desire to help others by doing this activity so that compassion in this person is not just sympathy or a pity reaction, but moreover, it can move me to be more knowing what other people are feeling and being able to experience emotions that are similar to those of others," (Princess).

\section{Happiness}

Prosocial behavior by helping other people or the community is often costly for the individual concerned, both materially and non-materially. However, prosocial behavior actually brings happiness benefits. Happiness is obtained for various reasons; Among other things, students see the happiness of others they help or feel relieved because they can help others.

"I feel happy to be given the opportunity to help ease the burden of suffering for the poor. There are many lessons that I can take, the lessons that I get in participating in helping these needy people. I learned how being grateful is important. Grateful for what we have. There are others who are not as lucky as us. We can also learn that making money is not easy, therefore use the money for useful purposes, don't easily waste the money we have," (Kartika).

\section{CONCLUSION}

This research concludes that descriptions above, the practice of prosocial education was evident in the Kemuhammadiyahan courses taught, thanks to the experiential learning approach applied in this course. Although in Indonesia, prosocial education has not received much attention from scholars but in the the international context, prosocial education is one of the important discourses aimed at so that education does not lose its vital elan with the surrounding community. This study shows that prosocial education can be practiced even in a religious subject. It can be said that this prosocial education is a religion-based prosocial education. Thus, this also contributes to contributing one variant of the implementation of prosocial education from an Islamic educational institution.

\section{REFERENCES}

Baehr, J. (2017). The Varieties of Character and Some Implications for Character Education. Journal Youth Adolescence 46, 1153-1161

Baidhawy, Zakiyuddin dan Azaki Khoirudin. (2017). Etika Muhammadiyah dan Spirit Peradaban. Yogyakarta: Suara Muhammadiyah.

Bathmaker, Ann-Marie et.all. (2016). Higher Education, Social Class, and Social Mobility: The Degree Generation. London: Palgrave Macmillan

Cheung, C. (2006). Experiential Learning Strategies for Promoting Adolescents' Voluntarism in Hong Kong. Child Youth 
Care Forum 35: 57-78. https://doi.org/10.1007/s10566-0059003-6

Coker, Jeffrey Scott, Evan Heiser, Laura Taylor, and Connie Book. (2017). Impacts of Experiential Learning Depth and Breadth on Student Outcomes, Journal of Experiential Education. Vol. 40 (1): $5-23$

D'Alessandro, Ann Higgins-. (2012). The Second Side of Education: Prosocial Development" dalam Philip M. Brown, Michael W. Corrogan, and Ann HigginsD'Alessandro. Handbook of Prosocial Education. UK: Rowmand \& Littlefiled Publisher

Haggarty, Linda. (1996) What is.....content analysis?. Journal Medical Teacher. Vol. 18 (1): 99-101

Kolb. David A. (2015). Experiental Learning: Experiences as Source of Learning and Development. New Jersey: Pearson Education.

Lai, Charlotte Sze-Yeung \& Patrick Chileung Hui. (2020). Service-learning: impacts of learning motivation and learning experience on extended social/civic engagement. Higher Education Research \& Development. doi: 10.1080/07294360.2020.1756748

Mundzir, Ilham dan Zamahsari. (2021). Pendidikan Prososial Berbasis AlMa'un: Jejak Anak-Anak Muda Berdayakan Duafa. Yogyakarta: Samudra Biru Oliner, Pearl M. (1986). Legitimating and Implementing Prosocial Education, Humbolt Journal of Social Relation. Vol.13 (1 \&2): 391-410

Olivola, Chrsitopher $\mathrm{Y}$ and Eldar Shafir. 2011. The Martyrdom Effect: When Pain and Effort Increase Prosocial
Contribution. Journal of Behavioral Decision Making. doi: 10.1002/bdm.767

Pasha, Musthafa Kamal dan Ahmad Adaby Darban, (2009). Muhammadiyah Sebagai Gerakan Islam. Yogyakarta: Pustaka Suara Muhammadiyah, 2009.

Spinrad, Tracy L and Diana E. Gal. (2018). Fostering Prosocial behavior and empathy in young children, Current Opinion in Psychology. Vol 20: 40-44

Spinrad, Tracy L. Spinrad and Diana L. Gal. (2017). Fostering Prosocial Behavior and Emphaty in Young Children, COPSYC, http://dx.doi.org/10.1016/j.copsyc.2017.0 8.004

Telle, Nills-Torge, Hans Rugider Psifter. (2015). Positive Empathy and Prosocial Behavior: A Neglected Link. Emotion Review. Vol 2 (2): 154-163

Tim Dosen AIK. (2018). Kemuhammadiyahan. Yogyakarta: Suara Muhammadiyah.

Tomkins, Leah and Eda Ulus. (2016). Oh, was that "experiential learning"?!' Spaces, synergies and surprises with Kolb's learning cycle. Journal Management Learning, Vol: 47 (2): 158178

Welply, Oakleigh. (2019). A crisis in education? An Arendtian perspective on citizenship and belonging in France and England. British Journal of Sociology of Education, 40 (6), 759-775, doi: 10.1080/01425692.2019.1592661

Yoner, Julie E Yonker, Adriene R Pendery, Christopher Klein, John Witte. (2019). Relational-based Christian practices of gratitude and prayer positively impact Christian university student's reported prosocial tendencies. International Journal of Christian and Education. Vol 23

(2):

150-17 